\title{
Review
}

\section{Amandine Pinto and Marc Pocard* \\ Hyperthermic intraperitoneal chemotherapy with cisplatin and mitomycin C for colorectal cancer peritoneal metastases: A systematic review of the literature}

https://doi.org/10.1515/pp-2019-0006

Received March 25, 2019; accepted May 10, 2019;

Previously published online May 29, 2019

\begin{abstract}
Background: The randomized trial PRODIGE 7 failed to show the benefit of oxaliplatin hyperthermic intraperitoneal chemotherapy (HIPEC) in colorectal peritoneal metastasis treatment (CR PM). This systematic review focuses on the association of cisplatin (CDDP) with mitomycin C (MMC) in HIPEC in CR PM.
\end{abstract}

Content: Experimental studies demonstrated that hyperthermia, in addition to $\mathrm{CDDP} \pm \mathrm{MMC}$ treatment, gradually improved the cytotoxic effect by increasing early apoptosis, eATP interaction, intracellular CDDP concentration (by 20\%) and p73 expression. Recent studies with highly selected patients reported unusual prolonged survival with a median overall survival (OS) of approximately 60 months, with a HIPEC combination of CDDP $\left(25 \mathrm{mg} / \mathrm{m}^{2} / \mathrm{L}\right)$ plus MMC $\left(3.3 \mathrm{mg} / \mathrm{m}^{2} / \mathrm{L}\right)$ at a temperature of $41.5-42.5^{\circ} \mathrm{C}$ for $60-90 \mathrm{~min}$. Major complications occurred in less than $30 \%$ of patients with limited hematological toxicity (less than 15\%). In addition, in a phase 2 trial, an adjuvant HIPEC benefit was demonstrated in colorectal cancer patients with high risk for peritoneal failure (5-year OS: $81.3 \%$ vs. $70 \%$ for the HIPEC group vs. the control group, respectively, $\mathrm{p}=0.047$ ). After a recurrence, an iterative procedure permitted similar recurrence-free disease (13 vs. 13.7 months) with an acceptable morbidity (18.7\% of severe complications).

Summary and outlook: The combination of CDDP and MMC seems to be an interesting protocol as an alternative to high-dose and short-term oxaliplatin.

*Corresponding author: Marc Pocard, U1275 - Carcinose Péritoine et Paris-Technologie, INSERM, Paris, France,

E-mail: marc.pocard@gmail.com

Amandine Pinto, Inserm U1275 - Carcinose Péritoine et Paris-

Technologie, INSERM, Paris, France, E-mail: amandine-pinto@live.fr
Keywords: cisplatin, colorectal peritoneal metastasis, HIPEC, mitomycin C

\section{Introduction}

Colorectal peritoneal metastasis (CR PM), with an occurrence rate of $40 \%[1,2]$, is the second most common colorectal metastatic disease after hepatic metastases (HM) [3]. Historically, PM was considered a terminal disease. However, the development of combined treatment involving cytoreductive surgery (CRS) and hyperthermic intraperitoneal chemotherapy (HIPEC) permitted the consideration of peritoneal metastasis (PM) as a metastatic step eligible for locoregional treatment [4-6]. The fundamental goal of this additional chemotherapeutic treatment is to maximize the total drug concentration in the peritoneal tumor nodules with passive diffusion [7] while minimizing that delivered to the systemic circulation [7]. This treatment permits a median survival of more than 40 months [4, 5, 8-10]. However, the HIPEC protocol is not standardized. Several chemotherapeutic drugs have been used for CR PM treatment: oxaliplatin [11], mitomycin C (MMC) [11] or cisplatinium (CDDP). However, there is no consensus on the applied dose, temperature and duration, carrier solution, perfusate volume and technique (open vs. closed) [11-13]. Oxaliplatin-based HIPEC has been developed by French teams since 2000, whereas MMC is the most commonly used drug worldwide [4, 14-16]. The survival results seem to be comparable for these two drugs [17-19], but oxaliplatin was preferred by many teams because of the duration of the HIPEC protocol (30 min with oxaliplatin vs. 60 or 90 min with $\mathrm{MMC}$ ), despite the increased risk of postoperative hemorrhage [20]. The number of published randomized trials on CRS and HIPEC is modest thus far, and this treatment will continue to face considerable methodological and practical challenges because of many HIPEC protocols, the choice of an adequate control group (CRS alone or combination chemotherapy?), the surgery in the experimental 
arm, and the long time period needed for the validity of the results [12, 13]. Recent results of the first phase III trial comparing CRS alone with CRS combined with HIPEC using oxaliplatin failed to demonstrate an overall survival advantage in the HIPEC arm, while the 60-day complication rate was significantly higher [21]. Ceelen proposed some potential explanations for the lack of benefit in the trial: oxaliplatin efficacy issues, adverse effects of intraperitoneal high dose glucose, and potential drawbacks of the use of hyperthermia [10]. Today, the PRODIGE 7 HIPEC protocol (oxaliplatin 30 min 360$460 \mathrm{mg} \mathrm{m}^{2} 43^{\circ}$ ) is abandoned, and the protocol must be redefined: indication, chemotherapy, time of hyperthermia, etc. Recently, the effectiveness of CDDP has been validated in ovarian peritoneal metastasis in a phase III trial offering a HIPEC solution [22]. Is it possible that HIPEC with CDDP has a place in CR PM treatment? In the literature, we note that several teams associate CDDP with MMC in CR PM treatment [23-27]. Would this association optimize the effectiveness of MMC HIPEC? This systematic review focuses on the association of CDDP in combination with MMC for HIPEC in CR PM.

\section{Materials and methods}

\section{Search strategy}

This systematic review agrees with the guidelines outlined in the preferred reporting items for systematic reviews and meta-analyses statement (PRISMA). On
PubMed, combinations of the following terms were used: "cisplatin," "peritoneal metastasis," "peritoneal carcinomatosis," "colorectal cancer," "experimental," "hyperthermia," "HIPEC” and "colon." We first identified 105 articles with the combination of "peritoneal carcinomatosis" AND "colorectal cancer" AND "cisplatin" and 132 articles with the combination of "experimental" AND "hyperthermia" AND "cisplatin" words. To expand this search, we analyzed 63 articles involving "colorectal cancer" AND "hyperthermia” AND "cisplatin,” 50 articles involving "colon" AND "hyperthermia” AND "cisplatin", and 37 articles with the combination of "colon" AND "HIPEC" AND "cisplatin". An initial screening of the title and abstracts was performed.

\section{Eligibility and data extraction}

Only studies including a surgical treatment of CR PM with HIPEC including cisplatin with/without MMC were selected. We first deleted duplicate articles and many articles about pressurized intraperitoneal aerosol chemotherapy - cancer (and no HIPEC). We separated experimental and clinical studies. The following studies were excluded: case-control studies, editorials, no fulltext available, and studies in languages other than English. Finally, we analyzed 22 articles: 13 clinical and 9 preclinical studies (Figure 1).

For clinical studies, we extracted the study design, number of patients, peritoneal cancer index, follow-up, postoperative mortality and morbidity and survival.

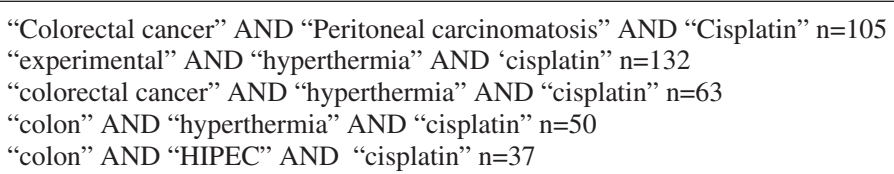




\section{Results}

\section{Experimental study}

\section{In vitro (Table 1)}

Some experimental studies demonstrated that hyperthermia can affect cell membranes, the cytoskeleton, and the synthesis of macromolecules and can increase drug-induced DNA damage and inhibit the repair of drug-induced DNA damage [28]. CDDP appeared as a drug of choice associated with hyperthermia because hyperthermia provided pharmacokinetic advantages with higher local CDDP concentrations in tissues [29]. First, in gastric cancer cell lines, Tang demonstrated a synergistic effect on inhibiting proliferation and induction of cell death via the apoptotic pathway [30]. In 2018, Cesna validated this synergic effect on colon cancer cells [28]. Caco-2 cells (colon cancer cell line) were treated with CDDP. Hyperthermia gradually improved the cytotoxic effect and decreased the viability of cells by one-fourth from $43^{\circ} \mathrm{C}$ to $45^{\circ} \mathrm{C}$. Furthermore, early apoptosis (20\% compared to cells treated in normothermia) and an increase in the intracellular CDDP concentration (by 20\%) were induced [28]. Some authors have investigated the role of adenosine triphosphate (ATP) in explaining the synergistic effect of chemotherapy and hyperthermia. ATP is basically undetectable in healthy tissues, whereas in the tumor interstitium, it was found in the hundreds of micromolar range [31]. Hyperthermia $\left(40^{\circ} \mathrm{C}\right)$ was noted to improve extracellular ATP-mediated cytotoxicity in MCA38 colon cancer cells [32]. With CDDP or MMC, hyperthermia and extracellular ATP together markedly potentiated cancer cell death [32]. The effects of hyperthermia on CDDP sensitivity were also proposed. Sotille [33] studied the effects of hyperthermia on CDDP sensitivity and determined whether MLH1 and MSH2 are associated with Hsp27 and Hsp72 in MMRdeficient(-)/-proficient(+) cells. We know that the MMR system (mismatch repair system) corrects mismatches and insertion/deletion loops generated during DNA replication, so the HCT116+ch2 (MMR-) and HCT116+ch3 (MMR+) cell lines were exposed to CDDP with or without previous hyperthermia $\left(42^{\circ} \mathrm{C}, 1 \mathrm{~h}\right)$. Whereas hyperthermia increased CDDP resistance in MMR-(1.42-fold), it potentiated CDDP sensitivity in MMR+inducing cell cycle arrest and increasing p73 expression [33]. Sotille first suggested that p73 might participate in the cellular response to hyperthermia and CDDP in an MMR-dependent manner.

In view of these interesting in vitro results, Bhagwandin [34] performed a translational study and proposed to evaluate the utility of in vitro drug sensitivity testing in 27 patients with peritoneal surface malignancies $(18.5 \%$ from colorectal origin, $n=5)$ undergoing CRS plus HIPEC (chemotherapy agents included MMC or CDDP alone). Seventeen tumors (63\%) displayed in vitro sensitivity to the agents used. However, there was no significant difference in survival for patients whose tumors displayed in vitro drug sensitivity vs. those whose tumors did not ( $\mathrm{p}=0.101$ and $\mathrm{p}=0.403$, respectively). There was no correlation between in vitro drug sensitivity and the histopathology of the primary neoplasm ( $\mathrm{p}=0.309)$. Today, it is not recommended to use these assays during the decision-making process in such patients because of the lack of clinical validation.

\section{In vivo (Table 1)}

The toxicity and effectiveness of the HIPEC procedure with MMC or CDDP were evaluated in preclinical studies.

Makrin showed that this procedure had a detrimental effect on the strength of colonic anastomosis, especially during the early postoperative period (until day 10) [35]. The bursting pressure of anastomoses in rats treated by HIPEC was significantly lower than in controls. On day 7 , it was $170,188,83$ and $19 \mathrm{mmHg}$ in groups $1-4$, respectively $(p<0.01)$ (1: surgery only, 2: HIPEC with saline, 3: HIPEC with MMC, and 4: HIPEC with CDDP). This detrimental effect on anastomotic bursting pressure was not observed $(\mathrm{p}=0.81)$ in a recent rat model [36].

The effectiveness of these HIPEC procedures was evaluated in two experimental studies.

Bevanda suggested the synergistic effect of hyperthermia, chemotherapy and immunotherapy and that interleukin-2 (IL-2) significantly increased antitumor activity and the survival rate of mice with CR PM [37]. He compared the cytostatics 5-FU $150 \mathrm{mg} / \mathrm{kg}$, CDDP 10 and MMC $5 \mathrm{mg} / \mathrm{kg}$ but did not test the CDDP-MMC association. Combined treatment with IL-2 and cytostatics (5-FU, CDDP or MMMC) significantly affected the development of peritoneal metastasis and increased the survival of mice: ILS\% (increased life span) at $37^{\circ} \mathrm{C}=29.88,199.32$ and 108.52 , ILS $\%$ at $43^{\circ} \mathrm{C}=62.69$, 260.50 and 178.05 , respectively). The most pronounced effect on survival was achieved by a combination of IL-2, CDDP and hyperthermia at $43^{\circ} \mathrm{C}\left(\mathrm{ILS} \%\right.$ at $37^{\circ} \mathrm{C}=199.32$ vs. 260.50 at $43^{\circ} \mathrm{C}$; $\mathrm{p}=0.01852$, Kaplan-Meier analysis).

More recently, Yun proposed the development of a novel hydrogel drug delivery system through the combination of 5-fluorouracil (5-FU)-loaded polymeric micelles and CDDP in biodegradable thermosensitive chitosan (CS) hydrogels [38]. The results suggest that intraperitoneal administration of CS hydrogel drug can inhibit tumor 
Table 1: Experimental studies about effect of hyperthermia and cisplatin \pm mitomycin C; main results.

\begin{tabular}{|c|c|c|}
\hline In vitro & $\begin{array}{l}\text { Chemotherapeutic } \\
\text { protocols }\end{array}$ & Aim and results \\
\hline Cesna [28] & $\begin{array}{l}\text { CDDP } \\
\text { Temperature: } \\
37^{\circ} \mathrm{C} \text { to } 45^{\circ} \mathrm{C}\end{array}$ & $\begin{array}{l}\text { Cytotoxicity: MTT assay } \\
-37^{\circ} \mathrm{C} \text { to } 42^{\circ} \mathrm{C} \text { : no significant effect } \\
-43^{\circ} \mathrm{C} \text { and } 44^{\circ} \mathrm{C} \text { : viability dropped by } 14 \% \text { and } 20 \% \text {, respectively } \\
\text { Cell apoptosis: Annexin V-PE flow cytometry } \\
\text { CDDP: induce early apoptosis } 1.5 \text {-fold } \\
\text { CDDP+ } 43^{\circ} \mathrm{C} \text { : induce early apoptosis as compared to cells treated in normothermia by } 20 \%(1 \% \text { of } \\
\text { dead cells) } \\
\text { Intracellular concentration of cisplatin: } \\
37^{\circ} \mathrm{C} \text { to } 43^{\circ} \mathrm{C} \text { : the concentration was significantly increased by } 20 \%\end{array}$ \\
\hline Tang [30] & $\begin{array}{l}\text { CDDP } \\
\text { Temperature: } \\
37^{\circ} \mathrm{C} \text { or } 43^{\circ} \mathrm{C}\end{array}$ & $\begin{array}{l}\text { Aim: to evaluate the impact of hyperthermia and hyperthermic chemotherapy on human gastric } \\
\text { cancer cell lines and to explore the mechanisms of cell-killing effect } \\
\text { Synergistic effect of hyperthermia and CDDP on inhibiting proliferation in each cell line } \\
\text { The cytotoxicity and proliferation inhibition of CDDP was dose-dependent/significant differences } \\
\text { between normothermic chemotherapy and hyperthermic chemotherapy with a CDDP concentration } \\
\text { range from } 0 \text { to } 16 \mu \mathrm{g} / \mathrm{mL} .^{\star} \mathrm{p}<0.05 ; \# p<0.01 \text {. } \\
\text { Hyperthermic chemotherapy induced cell death with two modes: apoptosis (more than } 50 \% \text { of cell } \\
\text { death occurred in early apoptosis) and necrosis }\end{array}$ \\
\hline $\begin{array}{l}\text { De Andrade } \\
\text { Mello [32] }\end{array}$ & $\begin{array}{l}\text { CDDP or MMC } \\
\text { Temperatures: } \\
37^{\circ} \mathrm{C}, 40^{\circ} \mathrm{C} \text { or } \\
42^{\circ} \mathrm{C}\end{array}$ & $\begin{array}{l}\text { Aim: to delineate the translatable strategy of hyperthermia to demonstrate impacts on P2X7 } \\
\text { responsiveness to eATP } \\
\text { Hyperthermia } \rightarrow \text { Increased membrane fluidity } \rightarrow \text { P } 2 X 7 \text { hyperactivation } \rightarrow \text { potentiate pore opening } \\
\text { and modulating downstream AKT/PRAS } 40 / \text { mTOR signaling events. } \\
\text { Combination CDDP or MMC, hyperthermia and eATP } \rightarrow \text { potentiate cancer cell death }\end{array}$ \\
\hline Sottile [33] & $\begin{array}{l}\text { CDDP } \\
\text { Temperature: } \\
42^{\circ} \mathrm{C}, 1 \mathrm{~h}\end{array}$ & $\begin{array}{l}\text { Aim: to study the effects of hyperthermia on CDDP sensitivity and to determine whether MLH1 and } \\
\text { MSH2 associate with Hsp27 and Hsp72 in MMR-deficient }(-) /- \text { proficient }(+) \text { cells } \\
\text { MMR- and MMR+cell lines were exposed to CDDP with or without previous hyperthermia } \\
\text { Clonogenic survival assay: } \\
\text { MMR- cells: hyperthermia increased CDDP resistance } 1.42 \text {-fold }(I C 50=17.60 \pm 2.10) \\
\text { MMR+cells: hyperthermia did not affect the number of colonies at concentrations lower than } 10 \mathrm{mM} \text {, } \\
\text { but it increased resistance at higher drug concentrations }(\mathrm{IC} 50=11.50 \pm 1.80) \\
\text { Immunofluorescence: to study Hsp } 27, \mathrm{Hsp} 72, \mathrm{MLH} 1 \text { and } \mathrm{MSH} 2 \text { proteins after CDDP: Hsp } 27 \text { and } \\
\text { Hsp72 translocated to the nucleus and colocalization coefficients between these proteins with MLH1 } \\
\text { and MSH2 increased in MMR+cells. } \\
\text { Western blotting and immunoprecipitation: confirmed the interactions between HSPs and MMR } \\
\text { proteins in control and treated cells } \\
\text { Cell cycle analysis: hyperthermia pretreatment induced cell cycle arrest, increased p73 expression } \\
\text { and potentiated CDDP sensitivity in MMR+cells. }\end{array}$ \\
\hline \multirow[t]{2}{*}{ Bhagwandin [34] } & $\begin{array}{l}\text { MMC, CDDP+DOX } \\
\text { or CDDP }\end{array}$ & $\begin{array}{l}\text { Aim: to evaluate the utility of in vitro drug sensitivity testing in patients with peritoneal surface } \\
\text { malignancies undergoing CRS+HIPEC }\end{array}$ \\
\hline & Alone & $\begin{array}{l}\text { Data for } 27 \text { patients } \\
\text { ChemoFx }{ }^{\circledR} \text { assay: results obtained and reported by Precision Therapeutics are grouped into three } \\
\text { categories: (1) responsive; ( } 2 \text { ) intermediate-responsive; }(3) \text { nonresponsive } \\
\text { In vitro chemosensitivity was noted in } 17 \text { patients ( } 63 \%) \text {. } \\
\text { NO significant differences in OS and PFS for patients whose tumors displayed in vitro drug sensitivity } \\
\text { versus those whose tumors did not ( } \mathrm{p}=0.101 \text { and } \mathrm{p}=0.403 \text {, respectively) }\end{array}$ \\
\hline
\end{tabular}


Table 1: (continued)

\begin{tabular}{|c|c|c|}
\hline In vitro & $\begin{array}{l}\text { Chemotherapeutic } \\
\text { protocols }\end{array}$ & Aim and results \\
\hline Makrin [35] & $\begin{array}{l}\text { Male Wistar rats } \\
(n=96)\end{array}$ & $\begin{array}{l}\text { Aim: to examine the influence of chemotherapy and hyperthermia on the healing of colonic } \\
\text { anastomosis } \\
\text { Colonic anastomosis } 2 \mathrm{~cm} \text { above the ileo-cecal joint } \\
\text { HIPEC protocol: closed } / 40^{\circ} \mathrm{C} / 20 \mathrm{~min} \\
\text { Bursting pressure of anastomoses significantly lower than in controls }(p<0.01) \text { : } \\
\text { Day } 4 \text { and 7: } \\
\text { Surgery only: } 54.8 \text { and } 170 \mathrm{mmHg} \\
\text { HIPEC with saline: } 38 \text { and } 188 \mathrm{mmHg} \\
\text { HIPEC with MMC: } 18 \text { and } 83 \mathrm{mmHg} \\
\text { HIPEC with CDDP: } 14.8 \text { and } 19 \mathrm{mmHg} \\
\text { The difference decreased on day } 10 \text { and almost vanished on day } 21\end{array}$ \\
\hline Aghayeva [36] & $\begin{array}{l}\text { Wistar Albino rats } \\
(\mathrm{n}=60)\end{array}$ & $\begin{array}{l}\text { Aim: to examine the influence of chemotherapy and hyperthermia on the healing of colonic } \\
\text { anastomosis } \\
\text { Sigmoid resection and end-to-end colorectal anastomosis } \\
\text { HIPEC: open } / 42^{\circ} / 60 \text { or } 90 \text { min } \\
\text { Bursting pressure of anastomosis: no difference }(p=0.81) \\
\text { Surgery only: } 70 \mathrm{mmHg} \\
\text { HIPEC with saline: } 70 \mathrm{mmHg} \\
\text { HIPEC with MMC: } 60 \mathrm{mmHg} \\
\text { HIPEC with CDDP: } 80 \mathrm{mmHg} \\
\text { HIPEC with OX: } 70 \mathrm{mmHg} \\
\text { HIPEC with DOX: } 80 \mathrm{mmHg}\end{array}$ \\
\hline Bevanda [37] & Mice & $\begin{array}{l}\text { Aim: to investigate the effect of local chemoimmunotherapy and HIPEC in a mouse model of induced } \\
\text { peritoneal metastasis } \\
\text { IL-2 was IP injected at day } 7 \text { and } 3 \text { before implantation of tumour cells } \\
2 \mathrm{~mL} \text { of saline heated to either } 37^{\circ} \mathrm{C} \text { or } 43^{\circ} \mathrm{C} \text { (hyperthermal treatment) and cytostatics followed } \\
\text { tumoral IP injection } \\
\text { Combined treatment with IL-2 and cytostatics (5-FU, CDDP or MMC) significantly increased the } \\
\text { survival of mice: } \\
\text { ILS } \%-37^{\circ} \mathrm{C}=29.88,199.32 \text {, and } 108.52, p=0.06 \text {, respectively } \\
\text { ILS } \%-43^{\circ} \mathrm{C}=62.69,260.50 \text {, and } 178.05, p=0.01 \text {, respectively }\end{array}$ \\
\hline Yun [38] & $\begin{array}{l}\text { BALB } / \text { c mice } \\
(n=108)\end{array}$ & $\begin{array}{l}\text { Aim: to investigate the antitumor activity of a novel hydrogel drug delivery system through the } \\
\text { combination of } 5 \text {-FU loaded polymeric micelles and CDDP in biodegradable thermosensitive chitosan } \\
\text { (CS) hydrogel. } \\
\text { Colorectal peritoneal metastasis (CT26 IP) and IP treatment } \\
\text { The mean number and weight of tumor nodules: } \\
\text { CS hydrogel drug group }(10.33 \pm 2.66,0.49 \pm 0.11 \mathrm{~g} \text { ) were clearly decreased compared saline group } \\
(53.83 \pm 9.99,2.31 \pm 0.38 \mathrm{~g}, \mathrm{p}<0.001), \text { blank micelles-hydrogel group }(52.67 \pm 6.12,2.26 \pm 0.28 \mathrm{~g} \text {, } \\
\mathrm{p}<0.001), 5 \text {-FU micelles group }(22.5 \pm 4.23,0.99 \pm 0.17 \mathrm{~g}, \mathrm{p}<0.001), \mathrm{CDDP} \text { loaded CS hydrogel group } \\
(23.33 \pm 3.56,0.98 \pm 0.13 \mathrm{~g}, \mathrm{p}<0.001), \mathrm{FU}+\mathrm{CDDP} \text { group }(18.16 \pm 3.06,0.79 \pm 0.13 \mathrm{~g}, \mathrm{p}<0.05) \\
\text { The median survival: } \\
\text { CS hydrogel drug group ( } 43 \text { days) was remarkably longer than saline group group ( } 25 \text { days), blank } \\
\text { micelles-hydrogel group ( } 26 \text { days), } 5 \text {-FU micelles group ( } 31 \text { days), CDDP loaded CS hydrogel group } \\
\text { ( } 33 \text { days), and FU+CDDP group ( } 35 \text { days) }\end{array}$ \\
\hline
\end{tabular}

MMC, mitomycin C; CDDP, cisplatin; OX, oxaliplatin; DOX, doxorubicine; IL-2, interleukin-2; 5-FU, 5-fluorouracil; IP, intra peritoneal; CS, biodegradable thermosensitive chitosan; ILS\%, percentage of increased life span; CRS, cytoreductive surgery; HIPEC, hyperthermic intraperitoneal chemotherapy; OS, overall survival; DFS, disease free survival. 
growth in a mouse model of CR PM. It permitted prolonged survival time compared with other groups $(\mathrm{p}<0.05)$. The median survival in the CS hydrogel drug group (43 days) was longer than those in the NS (control) group (25 days), blank micelle-hydrogel group (26 days), 5-FU micelle group (31 days), CDDP loaded CS hydrogel group (33 days), and FU+CDDP group (35 days). Ki-67 immunohistochemical analysis revealed that tumors in the CS hydrogel drug group had lower cell proliferation in contrast to other groups $(\mathrm{p}<0.001)$. Furthermore, hematoxylin-eosin staining of liver and lung tissue indicated that the CS hydrogel drug also had a certain inhibitory effect on colorectal cancer metastasis to the liver and lung.

Taken together, all experimental results suggest that CDDP and MMC are efficient drugs to control CR MP and that CDDP is more active in a hyperthermic situation.

\section{Clinical results}

\section{HIPEC protocol (Table 2)}

The HIPEC protocol with CDDP and MMC is not standardized. These two chemotherapeutic agents were mainly described by Italian teams. They were the first to publish this HIPEC protocol with oncological results. Cavaliere, in 2000 [39], published an open technique with CDDP $\left(25 \mathrm{mg} / \mathrm{m}^{2} / \mathrm{L}\right)$ plus MMC $\left(3.3 \mathrm{mg} / \mathrm{m}^{2} / \mathrm{L}\right)$ at a temperature of $41.5-42.5^{\circ} \mathrm{C}$ for $90 \mathrm{~min}$. The same year, he published a second study with the same protocol [40]. In 2011, he prospectively collected clinical data for 146 patients treated in five Italian hospitals for CR PM with CRS/HIPEC [41]. The choice of perfusion modality (open, semiclosed or closed) was left to the operator. However, the drugs perfused were the same as in the first studies, that is, CDDP $25 \mathrm{mg} / \mathrm{m}^{2} / \mathrm{L}$ of perfusate or CDDP $25 \mathrm{mg} / \mathrm{m}^{2} / \mathrm{L}$ plus MMC $3.3 \mathrm{mg} / \mathrm{m}^{2} / \mathrm{L}$, and perfusion lasted $60-90 \mathrm{~min}$ at $41.5-43^{\circ} \mathrm{C}$. Baratti published three studies [23-25] evaluating the same HIPEC protocol with $\mathrm{CDDP}+\mathrm{MMC}$ to treat CR PM. He proposed a closed-abdomen HIPEC protocol with the same drug concentrations for $60 \mathrm{~min}$ at a temperature of $42.5^{\circ} \mathrm{C}$. Pilati [42] published another Italian experience with this HIPEC protocol. Vaira in 2010 [44] proposed a HIPEC protocol according to the original semiclosed abdomen technique, with CDDP $100 \mathrm{mg} / \mathrm{m}^{2}$ plus MMC $16 \mathrm{mg} / \mathrm{m}^{2}$ at a temperature of $41.5^{\circ} \mathrm{C}$ for $60 \mathrm{~min}$.

Two Japanese teams described HIPEC with these two chemotherapeutic agents. Yonemura [43] used the same CDDP plus MMC HIPEC protocol as Cavaliere [39, 40] and Baratti [23-25]. Huang [26] used $120 \mathrm{mg}$ of CDDP and
$30 \mathrm{mg}$ of MMC, each dissolved in $6 \mathrm{~L}$ of heated saline (drug concentrations: CDDP $20 \mathrm{mg} / \mathrm{mL}, \mathrm{MMC} 5 \mathrm{mg} / \mathrm{mL}$ ), for $90 \mathrm{~min}$ at a temperature of $43.0 \pm 0.5^{\circ} \mathrm{C}$.

In 2016, Lin [27] published team results in Taiwan with $100 \mathrm{mg}$ of CDDP plus $20 \mathrm{mg}$ of MMC for $60 \mathrm{~min}$ at $42-43^{\circ} \mathrm{C}$.

\section{Postoperative morbidity (Table 2)}

Postoperative mortality after CRS/HIPEC CR PM treatment with $\mathrm{CDDP} \pm \mathrm{MMC}$ was described between $0 \%$ [42] and 3\% [25], equivalent to the oxaliplatin HIPEC protocol [26]. Major complications occurred is less than $30 \%$ (27\% in the more recent study) [23-27, 41-44], mostly related to anastomotic leakage, intestinal fistula, abdominal abscess and pleura effusion, with approximately 10\% reoperations. Hematological toxicity appeared in less than $15 \%[25,42,44]$ and hemorrhage between $1 \%$ [24] and $2 \%$ [26]. These results contrasted with oxaliplatin intraperitoneal toxicity. Hemoperitoneum $(22.7 \%)$ and grade $3 / 4$ thrombocytopenia (13.3\%) were the most frequently reported toxicities with the oxaliplatin HIPEC protocol [45].

\section{Long-term outcomes and recurrence (Table 2)}

The median survival rates described for patients treated with HIPEC were very different, from 16 [26] to 60.1 months [22]. Five-year overall survival also appeared very different, between 22\% [26] and 58.8\% [25].

The peritoneal carcinomatosis index (PCI) could explain these survival differences. The majority of patients (53\%) treated in Huang's study [26] had an important PM (PCI>20), with a median PCI at 21, whereas Baratti, in a recent study [24], showed survival of patients with a limited PM (median PCI=10). In a multivariate logistic regression analysis, Baratti confirmed that PCI $>19$ (OR, 2.6; 95\% CI, 1.1-6.0; $\mathrm{p}=0.02$ ) was an independent predictive factor for major complications [25].

In addition, Baratti demonstrated that major complications independently affect long-term disease-specific survival (DSS) [25]. Five-year DSS was 14.3\% (median, 18.5 months; 95\% CI, 15.7-21.1) for patients who experienced major complications and 52.3\% (median, 62.8; 95\% CI, 23.9-101.7) for those who did not.

Extraperitoneal metastasis appeared as another pejorative survival criterion. In 2018, Baratti [24] compared the long-term outcomes between patients who had CRS/HIPEC for PM alone ( $\mathrm{n}=121,81.1 \%)$ and patients 
Table 2: Hyperthermic intraperitoneal chemotherapy with cisplatin and mitomycin C for colorectal cancer peritoneal metastases: main results.

\begin{tabular}{|c|c|c|c|c|c|c|}
\hline Author & Year & Patients, $n$ & PCI (median) & $\begin{array}{r}\text { Follow up } \\
\text { (median) }\end{array}$ & Survival & $\begin{array}{l}\text { Post-operative mortality/ } \\
\text { morbidity }\end{array}$ \\
\hline Cavaliere [39] & 2000 & $35(n=11$ CRPC $)$ & 16 & $17 \mathrm{mo}$ & $\begin{array}{l}\text { Median OS: } 26 \text { mo } \\
2 \text { year OS: } 55.2 \text { mo } \rightarrow 54.7 \% \\
\text { for CRPC }\end{array}$ & Major complications: $37 \%$ \\
\hline Cavaliere [40] & 2000 & $40(n=14$ CRPC $)$ & 16 & $20 \mathrm{mo}$ & $\begin{array}{l}\text { Median OS: } 30 \mathrm{mo} \\
2 \text { year OS: } 61.4 \% \rightarrow 63.5 \% \text { for } \\
\text { CRPC }\end{array}$ & Major complications: $35 \%$ \\
\hline Cavaliere [41] & 2011 & 146 & $\begin{array}{r}<11: 33 \% \\
11-20: 49 \% \\
>20: 18 \%\end{array}$ & $19 \mathrm{mo}$ & $\begin{array}{l}\text { Median OS: } 21 \text { mo } \\
2 \text { year OS: } 45 \% \\
2-3 \text { year DFS: } 33 \%-26 \%\end{array}$ & $\begin{array}{l}\text { Mortality: } 3.4 \% \\
\text { Major complications: } 27.4 \%\end{array}$ \\
\hline Pilati [42] & 2003 & 34 & & $14.5 \mathrm{mo}$ & $\begin{array}{l}\text { Median OS: } 18 \mathrm{~m} \\
\text { Median RFS: } 13 \text { mo } \\
2 \text { year OS-2 year RFS: } 31 \% \\
-10 \%\end{array}$ & $\begin{array}{l}\text { Mortality: } 0 \\
\text { Morbidity: } 36 \%\end{array}$ \\
\hline Yonemura [43] & 2013 & $\begin{array}{r}142 \\
\text { HIPEC: } 87 \\
\text { No HIPEC: } 55\end{array}$ & $\begin{array}{l}\leq 10: 53 \% \\
>10: 47 \%\end{array}$ & & $\begin{array}{l}\text { Median OS: } 24 \mathrm{mo} \\
5 \text { year OS: } 23.4 \% \\
\text { Multivariate cox regression: CC } \\
\text { score, histology, } \mathrm{PCl} \leq 10\end{array}$ & $\begin{array}{l}\text { Mortality: } 0.7 \% \\
\text { Major complications: } 17.6 \% \\
\text { Morbidity: } 42.9 \%\end{array}$ \\
\hline Baratti [25] & 2014 & 101 & 10 & $44.9 \mathrm{mo}$ & $\begin{array}{l}\text { Major morbidity: } 5 \text { year OS: } \\
11.7 \%\end{array}$ & Mortality: $3 \%$ \\
\hline & & $\begin{array}{r}\text { Major } \\
\text { morbidity: } 24\end{array}$ & & & $\begin{array}{l}\text { No major morbidity: } 5 \text { year OS: } \\
58.8 \%\end{array}$ & Major complications: $23.8 \%$ \\
\hline & & $\begin{array}{r}\text { No major } \\
\text { morbidity: } 77\end{array}$ & & & $\begin{array}{l}\text { Multivariate cox regression: } \\
\text { major morbidity, } \mathrm{PCl}>19, \mathrm{CC} \\
\text { score }\end{array}$ & Reoperation: $10 \%$ \\
\hline Baratti [24] & 2018 & $\begin{array}{r}148 \\
\text { PC: } 121\end{array}$ & $\begin{array}{r}10 \\
\text { PC: } 10\end{array}$ & $34.6 \mathrm{mo}$ & $\begin{array}{l}\text { PC+EPM: } \\
\text { Median OS } 19 \text { mo }\end{array}$ & $\begin{array}{l}\text { Mortality: } 3.4 \% \\
\text { Major complications: } 27.7 \% \\
\text {-> } 61 \% \text { cases presented }\end{array}$ \\
\hline & & PC+EPM: 27 & $\underline{\mathrm{PC}+\mathrm{EPM}}: 8.5$ & & $\begin{array}{l}\text { Median RFS: } 9.6 \mathrm{mo} \\
5 \text { year OS }=16.5 \% \\
\text { PC alone: } \\
\text { Median OS: } 60.1 \mathrm{mo} \\
\text { Median RFS: } 13.8 \mathrm{mo} \\
5 \text { year OS }=52 \%\end{array}$ & $\begin{array}{l}\text { PC+EPM } \\
\text { Morbidity/systemic toxicity: } \\
\text {-PC+EPM: } 55.6 \% / 27.8 \% \\
\text {-PC alone: } 20.8 \% / 3.8 \%\end{array}$ \\
\hline Huang [26] & 2014 & 60 & $\begin{array}{r}21 \\
\leq 20: 47 \% \\
>20: 53 \%\end{array}$ & $29.9 \mathrm{mo}$ & $\begin{array}{l}\text { Median OS: } 16.0 \\
5 \text { year OS: } 22 \% \\
1-2-3-5 \text { year OS: } \\
70.5 \%-34.2 \%-22 \%-22 \% \\
\text { Multivariate cox regression: CC } \\
\text { score, post-operative adjuvant } \\
\text { chemotherapy }\end{array}$ & $\begin{array}{l}\text { Mortality: } 0 \% \\
\text { Major complications: } 30.2 \%\end{array}$ \\
\hline Lin [27] & 2016 & 31 & 16 & & $\begin{array}{l}2-5 \text { year OS: } 57 \%-38 \% \\
\text { Multivariate cox regression: } \\
\text { PPCI score }\end{array}$ & $\begin{array}{l}\text { Mortality: } 0 \% \\
\text { Major complications: } 0 \% \\
\text { Morbidity: } 21 \%\end{array}$ \\
\hline Vaira [44] & 2010 & 40 & $\begin{array}{r}\text { Group A (before } \\
2002): 15,4 \\
\text { Group B } \\
\text { (2002-2008): } 10,7\end{array}$ & & $\begin{array}{l}\text { Group A: median OS } \\
16.7 \text { months } \\
\text { Group B: median OS } \\
24.6 \text { months }\end{array}$ & $\begin{array}{l}\text { Mortality: } 2.5 \% \\
\text { Morbidity: } 55 \%\end{array}$ \\
\hline
\end{tabular}

OS, overall survival; DFS, disease free survival; RFS, recurrence free survival; Mo, months; CR PC, colorectal peritonealcarcinomatosis; HIPEC, hyperthermic intraperitoneal chemotherapy; PCl, peritoneal carcinomatosis index; PC, peritoneal carcinomatosis; EPD, extra peritoneal disease. 
undergoing curative-intent treatments for extraperitoneal disease (EPD) ( $\mathrm{n}=27,18.2 \%, 85 \%$ had liver metastasis). The five-year OS was 52.0\% (median=60.1months; 95\% CI, 44.9-93.7) for 121 patients treated for PM alone vs. 16.5\% (median=19.0 months; 95\% CI, 12.1-30.4) for 27 patients treated for EPD, $\mathrm{p}=0.019$.

\section{Prophylactic HIPEC}

Two authors, namely, Virzi and Baratti, evaluated the HIPEC protocol with CDDP and MMC at the time of primary curative surgery in patients with colorectal cancer at high risk for metachronous peritoneal metastases [23, 46].

Virzi published [46] a prospective pilot study with 12 patients to assess the feasibility, safety and efficacy of this same HIPEC protocol combined with primary curative surgery in colorectal cancer at high risk for peritoneal metastases (minimal synchronous peritoneal involvement, synchronous ovarian metastases, primary tumor, either directly invading other organs or penetrating visceral peritoneum, and positive peritoneal washing cytological examination). The protocol was well tolerated and safe. Major morbidity occurred in $17 \%$ of cases and operative death in none. The 5-year progression-free and peritoneal progression-free survival rates were $74.1 \%$ and $90.9 \%$, respectively. The 5-year overall survival was $83.3 \%$, although one patient died shortly after 5 years.

Baratti [23] published a phase 2 study in 2016 that assessed adjuvant HIPEC in colorectal cancer patients at high risk for metachronous peritoneal metastasis (minimal synchronous peritoneal metastasis, synchronous ovarian metastases, primary tumor either penetrating the visceral peritoneum or directly invading other organs, age $<=75$ years, WHO performance score $<=2$, no significant comorbidities, and signed informed consent). He included a number of patients included in the study by Virzi et al., as the latter was a preliminary report of the Italian experience with prophylactic HIPEC. A total of 22 patients without systemic metastases were prospectively enrolled in two centers to receive HIPEC simultaneously with curative surgery. A control group retrospectively included 44 matched (1:2) patients undergoing standard treatments. The Kaplan-Meier estimated 5-year overall survival (OS) was $81.3 \%$ in the HIPEC group vs. $70.0 \%$ in the control group $(\mathrm{p}=0.047)$. No operative death occurred, and severe morbidity rates were $18.2 \%$ in the HIPEC group and $25 \%$ in controls $(\mathrm{p}=0.75)$. In multivariate analysis, HIPEC correlated with a lower cumulative incidence of PM (hazard ratio [HR] 0.04, 95\% CI 0.01$0.31 ; \mathrm{p}=0.002$ ), better OS (HR 0.25, 95\% CI 0.07-0.89; $\mathrm{p}=0.039$ ) and progression-free survival (HR 0.31, 95\% CI $0.11-0.85 ; p=0.028)$. He concluded that adjuvant HIPEC may benefit these patients with a high risk of peritoneal failure.

\section{What is the best treatment after a recurrence?}

In some cases, after CR PM treatment by CRS/HIPEC, recurrences may be confined to the peritoneal cavity and are completely resectable. Vaira [47] evaluated the results of 16 patients presenting with isolated peritoneal recurrence who had undergone iterative CRS and HIPEC [47]. Only patients with $\mathrm{PCI} \leq 16$ and a progression-free interval of at least 12 months between the first HIPEC and the recurrence diagnosis and patients with completely resected disease received a second HIPEC. Colonic tumors perfused using $100 \mathrm{mg} / \mathrm{m}^{2} \mathrm{CDDP}$ and $16 \mathrm{mg} / \mathrm{m}^{2} \mathrm{MMC}$ at the first intervention were perfused at the second with $35 \mathrm{mg} / \mathrm{m}^{2} \mathrm{MMC}$. The median interval between the initial and second CRS with HIPEC was 19 months (range 12-111 months). The mean PCI was 8 vs. 16 for the first procedure. No patient died postoperatively, and the overall morbidity was $43.7 \%$, with $18.7 \%$ severe complications. After a median follow-up of 20 months, RFS following repeated CRS and HIPEC was comparable (13 vs. 13.7 months) to that registered after the first procedure.

\section{Discussion}

Residual microscopic metastases after cytoreductive surgery remain a therapeutic challenge. The adjuvant application of intraperitoneal chemotherapy has become the standard of care. However, the chemotherapeutic drug protocol is not standardized. In 2018, two randomized phase III studies evaluated combined therapy (CRS+HIPEC) vs. CRS alone for peritoneal metastases. PRODIGE 7 failed to show a difference in overall survival between patients treated with oxaliplatin HIPEC adjunction for CR PM. Overall survival was high in both groups but did not differ significantly (41.7 vs. 41.2 months in the HIPEC and control arm, respectively, HR 1.00 [95\% CI: 0.73-1.37) [21]. In parallel, Van Driel [22] validated the effectiveness of HIPEC adjunction with CDDP in ovarian peritoneal metastasis. He showed the effectiveness of CDDP HIPEC on recurrence and overall survival [22]: $89 \%$ vs. $81 \%$ and 33.9 vs. 45.7 months for cytoreductive surgery alone or in association with HIPEC, respectively $(p=0.003)$. These two major clinical trials have disturbed the expert community [48]. The PRODIGE 7 results were the 
object of intensive discussions among HIPEC surgeons during the last meeting of the Peritoneal Surface Oncology Group International (PSOGI) in Paris on 9-11 September 2018 [48]. Ceelen [10] and other experts [48] proposed some potential explanations for the lack of benefit, including oxaliplatin efficacy issues, adverse effects of intraperitoneal high dose glucose, and potential drawbacks of the use of hyperthermia. The HIPEC protocol for the treatment of CR PM must be redefined: indication, chemotherapy and time of hyperthermia. We were interested in CDDP's place in this indication. Today, we have no comparative data showing the superiority of MMC alone or associated with CDDP over other HIPEC regimens or a survival advantage of CRS-HIPEC with MMC over modern palliative systemic chemotherapy. Few experimental studies evaluated this protocol in CR PM, but they suggested that CDDP and MMC were efficient drugs to control CR MP and that CDDP was more active in a hyperthermic situation. The most frequently described protocol consists of the combination of CDDP $\left(25 \mathrm{mg} / \mathrm{m}^{2} / \mathrm{L}\right)$ plus MMC $\left(3.3 \mathrm{mg} / \mathrm{m}^{2} / \mathrm{L}\right)$ at a temperature of $41.5-42.5^{\circ} \mathrm{C}$ for $60-90 \mathrm{~min}$. The survival results described for patients treated with HIPEC combined with CDDP and MMC were very different. We first explain these differences by the peritoneal carcinomatosis index (PCI), which is a very different function of cohorts. However, PCI has been demonstrated by many multivariate analyses to be the most important adverse prognostic factor after CRS-HIPEC [24, $25,27,43,49]$. It is important to note that patients treated for PM alone had a very important OS survival (60 months), equivalent or higher than that of patients receiving oxaliplatin IP $[10,19,50]$. Concerning HIPEC morbidity with CDDP, Van Driel [22] did not note an increasing risk of postoperative complications (major morbidity: 25\% and $27 \%$ for surgery alone vs. the surgery-plus-HIPEC group, $\mathrm{p}=0.76$ ). In the CR PM literature, major complications occurred in less than $30 \%$ ( $27 \%$ in the more recent study). Taken together, all results indicated that the drug concentration, carrier solution, level of hyperthermia or duration is possibly related to the postoperative high complication rate level. For example, 5\% dextrose, an oxaliplatin carrier solution, causes metabolic and electrolyte shifts (hyperglycemia and hyponatremia), which may exacerbate surgical morbidity [10]. No clinical studies comparing normothermic with hyperthermic chemoperfusion permit validation of the adverse effects of hyperthermia. However, it is admitted that toxicities within the peritoneal cavity, such as small bowel fistula and anastomotic leakage, undoubtedly increase as the area under the curve for drug dose increases [6]. Regarding the effectiveness and safety, this Italian HIPEC protocol with a combination of CDDP $\left(25 \mathrm{mg} / \mathrm{m}^{2} / \mathrm{L}\right)$ plus MMC $\left(3.3 \mathrm{mg} / \mathrm{m}^{2} / \mathrm{L}\right)$ at a temperature of $41.5-42.5^{\circ} \mathrm{C}$ for $60-90$ min could be the rational base to support the design of future randomized trials vs. cytoreductive surgery alone in the treatment of colorectal PM. This protocol represents a potential alternative for now. We expect, in the next 10 years, new drug delivery systems, immunotherapy combined with chemotherapeutic, and development of nanovectorization, a new therapeutic area, to improve actual survival and decrease morbidity [51].

Today, the CDDP+MMC-based HIPEC is the only protocol to demonstrate an adjuvant HIPEC benefit in colorectal cancer patients at high risk for peritoneal failure (5-year overall survival: $81.3 \%$ vs. $70 \%$ for the HIPEC group vs. the control group, respectively, $\mathrm{p}=0.047$ ) [23]. During 2006-2012, a total of 22 patients without systemic metastases were prospectively enrolled to receive HIPEC simultaneously with curative surgery. A control group retrospectively included 44 matched (1:2) patients undergoing standard treatments and no HIPEC during the same period. PROPHYLOCHIP, a phase III randomized trial, evaluated surveillance vs. a systematic surgical look with oxaliplatin HIPEC at the end of adjuvant chemotherapy for colorectal cancers operated with a high risk of peritoneal metastasis (perforated tumor, ovarian metastasis, minimal peritoneal disease resected at the same time as the primitive). The results were presented at the 2018 ASCO (American Society of Clinical Oncology) meeting (Goéré, A3531). The Tris trial randomized 150 patients between surveillance and second surgery. Disease-free survival and overall survival at 3 years were not different: $44 \%$ vs. $51 \%$ and $79 \%$ vs. $80 \%$, NS, (second look vs. surveillance, respectively).

The combination of CDDP and MMC might be a valid HIPEC protocol in CR PM. Recent studies evaluating this protocol demonstrated prolonged survival (overall survival approximately 60 months) with limited toxicity. Major complications occurred in less than $30 \%$ of cases with few hematological toxicities (less than 15\%). This protocol is the only one to demonstrate an adjuvant HIPEC benefit for CRC patients at high risk for peritoneal failure (5-year overall survival $81.3 \%$ vs. $70 \%$ for the HIPEC group vs. the control group, respectively $[p=0.047]$ ). After a recurrence, an iterative procedure is possible with similar recurrence-free disease (13 vs. 13.7 months) and acceptable morbidity (18.7\% severe complications). Randomized trials are now needed to confirm this hypothesis.

Author contributions: All the authors have accepted responsibility for the entire content of this submitted manuscript and approved submission. 
Research funding: None declared.

Employment or leadership: M. Pocard is an expert consultant for GAMIDA company. M. Pocard had commercial relationships with ROCHE, SANOFI, ETHICON company, and Capnomed.

Honorarium: None declared.

Competing interests: The funding organization(s) played no role in the study design; in the collection, analysis, and interpretation of data; in the writing of the report; or in the decision to submit the report for publication.

\section{References}

1. Koppe MJ, Boerman OC, Oyen WJ, Bleichrodt RP. Peritoneal carcinomatosis of colorectal origin: incidence and current treatment strategies. Ann Surg. 2006;243:212-22.

2. Klaver YL, Lemmens VE, Nienhuijs SW, Luyer MD, de Hingh IH. Peritoneal carcinomatosis of colorectal origin: incidence, prognosis and treatment options. World J Gastroenterol. 2012;18:5489-94.

3. Klaver CE, Musters GD, Bemelman WA, Punt CJ, Verwaal VJ, Dijkgraaf MG, et al. Adjuvant hyperthermic intraperitoneal chemotherapy (HIPEC) in patients with colon cancer at righ risk of peritoneal carcinomatosis; the COLOPEC randomizerd muticentre trial. BMC Cancer. 2015;15:428.

4. Elias D, Gilly F, Boutitie F, Quenet F, Bereder JM, Mansvelt B, et al. Peritoneal colorectal carcinomatosis treated with surgery and perioperative intraperitoneal chemotherapy: retrospective analysis of 523 patients from a multicentric French study. J Clin Oncol. 2010;28:63-8.

5. Elias D, Lefevre JH, Chevalier J, Brouquet A, Marchal F, Classe JM, et al. Complete cytoreductive surgery plus intraperitoneal chemohyperthermia with oxaliplatin for peritoneal carcinomatosis of colorectal origin. J Clin Oncol. 2009;27:681-5.

6. Sugarbaker PH, Ryan DP. Cytoreductive surgery plus hyperthermic perioperative chemotherapy to treat peritoneal metastases from colorectal cancer: standard of care or an experimental approach ? Lancet Oncol. 2012;13:362-9.

7. Yan TD, Cao CQ, Munkholm-Larsen S. A pharmacological review on intraperitoneal chemotherapy for peritoneal malignancy. World J Gastrointest Oncol. 2010;2:109-16.

8. Chua TC, Yan TD, Zhao J, Morris DL. Peritoneal carcinomatosis and liver metastases from colorectal cancer treated with cytoreductive surgery perioperative intraperitoneal chemotherapy and liver resection. Eur J Surg Oncol. 2009;35:1299-305.

9. Quenet F, Goéré D, Mehta SS, Roca L, Dumont F, Hessissen M, et al. Results of two Bi-institutional prospective studies using intraperitoneal oxaliplatin with or without irinotecan during HIPEC after cytoreductive surgery for colorectal carcinomatosis. Ann Surg. 2011;254:294-301.

10. Ceelen W. HIPEC with oxaliplatin for colorectal peritoneal metastasis: the end of the road? 2018. Eur J Surg Oncol. 2019;45:400-2.

11. Van der Speeten K, Lemoine L, Sugarbaker P. Overview of the optimal perioperative intraperitoneal chemotherapy regimens used in current clinical practice. Pleura Peritoneum. 2017;2:63-72.
12. Eveno C, Pocard M. Randomized controlled trials evaluating cytoreductive surgery (CRS) and hyperthermic intraperitoneal chemotherapy (HIPEC) in prevention and therapy of peritoneal metastasis: a systematic review. Pleura Peritoneum. 2016;1:169-82.

13. Reymond MA. The quest of cytoreductive surgery (CRS) and hyperthermic intraperitoneal chemotherapy (HIPEC): searching for evidence. Pleura Peritoneum. 2016;1:167-8.

14. Elias D, El Otmany A, Bonnay M, Paci A, Ducreux M, Antoun S, et al. Human pharmacokinetic study oh heated intraperitoneal oxaliplatin in increasingly hypotonic solutions after complete resection of peritoneal carcinomatosis. Oncology. 2002;63:346-52.

15. Elias D, Pocard M, Sideris L, Edè C, Ducreux M, Boige V, et al. Preliminary results of intraperitoneal chemohyperthermia with oxaliplatin in peritoneal carcinomatosis of colorectal origin. Br J Surg. 2004;91:455-6.

16. Glehen O, Gilly FN, Boutitie F, Bereder JM, Quenet F, Sideris L, et al. Toward curative treatment of peritoneal carcinomatosis from nonovarian origin by cytoreductive surgery combined with perioperative intraperitoneal chemotherapy: a multi-institutional study of 1,290 patients. Cancer. 2010;116:5608-18.

17. Hompes D, D'Hoore A, Wolthuis A, Fieuws S, Mirck B, Bruin S, et al. The use of oxaliplatin or mitomycin $C$ in HIPEC treatment for peritoneal carcinomatosis from colorectal cancer: a comparative study. J Surg Oncol. 2014;109:527-32.

18. Van Eden WJ, Kok NF, Woensdregt K, Huitema AD, Boot $H$, Aalbers AGJ. Safety of intraperitoneal Mitomycin $C$ versus intraperitoneal oxaliplatin in patients with peritoneal carcinomatosis of colorectal cancer undergoing cytoreductive surgery and HIPEC. Eur J Surg Oncol. 2018;44:220-7.

19. Prada-Villaverde A, Esquivel J. The American Society of peritoneal Surface Malignancies evaluation of HIPEC with mitomycin C versus Oxaliplatin in 539 patients with colon cancer undergoing a complete cytoreductive surgery. J Surg Oncol. 2014;21:2608-14.

20. Charrier T, Passot G, Peron J, Maurice C, Gocevska S, Quenet F, et al. Cytoreductive surgery combined with hyperthermic intraperitoneal chemotherapy with oxaliplatin increases the risk of postoperative hemorrhagic complications: analysis of predictive factors. Ann Surg Oncol. 2016;23:2315-22.

21. Quenet F, Elias D, Roca L, Goere D, Ghouti L, Pocard M, et al. A UNICANCER phase III trial of hyperthermic intra-peritoneal chemotherapy (HIPEC) for colorectal peritoneal carcinomatosis (PC): PRODIGE 7. J Clin Oncol. 2018;36:1.

22. Van Driel WJ, Koole SN, Sikorska K, Schagen van Leeuwen JH, Schreuder HW, Hermans RH, et al. Hyperthermic intraperitoneal chemotherapy in ovarian cancer. $\mathrm{N}$ Engl J Med. 2018;378:230-40.

23. Baratti D, Kusamura S, lusco D, Gimondi S, Pietrantonio F, Milione $\mathrm{M}$, et al. Hyperthermic intraperitoneal chemotherapy (HIPEC) at the time of primary curative surgery in patients with colorectal cancer at high risk for metachronous peritoneal metastases. Ann Surg Oncol. 2017;24:167-75.

24. Baratti D, Kusamura S, lusco D, Cotsoglou C, Guaglio M, Battaglia L, et al. Should a history of extraperitoneal disease be a contraindication to cytoreductive surgery and hyperthermic intraperitoneal chemotherapy for colorectal cancer peritoneal metastases? Dis Colon Rectum. 2018;61:1026-34.

25. Baratti D, Kusamura S, lusco D, Bonomi S, Grassi A, Virzì S, et al. Postoperative complications after cytoreductive surgery 
and hyperthermic intraperitoneal chemotherapy affect longterm outcome of patients with peritoneal metastases from colorectal cancer: a two-center study of 101 patients. Dis Colon Rectum. 2014;57:858-68.

26. Huang CQ, Yang XJ, Yu Y, Wu HT, Liu Y, Yonemura Y, et al. Cytoreductive surgery plus hyperthermic intraperitoneal chemotherapy improves survival for patients with peritoneal carcinomatosis from colorectal cancer: a phase II study from a Chinese center. PLoS One. 2014;9:e108509.

27. Lin EK, Hsieh MC, Chen CH, Lu YJ, Wu SY. Outcomes of cytoreductive surgery and hyperthermic intraperitoneal chemotherapy for colorectal cancer with peritoneal metastasis. Medicine. 2016;95:e5522.

28. Cesna V, Sukovas A, Jasukaitiene A, Naginiene R, Barauskas G, Dambrauskas Z, et al. Narrow line between benefit and harm: additivity of hyperthermia to cisplatin cytotoxicity in different gastrointestinal cancer cells. World J Gastroenterol. 2018;24:1072-83.

29. Ried M, Potzger T, Braune N, Diez C, Neu R, Sziklavari Z, et al. Local and systemic exposure of cisplatin during hyperthermic intrathoracic chemotherapy perfusion after pleurectomy and decortication for treatment of pleural malignancies. J Surg Oncol. 2013;107:735-40.

30. Tang R, Zhu ZG, Qu Y, Li JF, Ji YB, Cai Q, et al. The impact of hyperthermic chemotherapy on human gastric cancer cell lines: preliminary results. Oncol Rep. 2006;16:631-41.

31. Pellegatti P, Raffaghello L, Bianchi G, Piccardi F, Pistoia V, Di Virgilio F. Increased level of extracellular ATP at tumor sites: in vivo imaging with plasma membrane luciferase. PLoS One. 2008;3:e2599.

32. De Andrade Mello P, Bian S, Savio LE, Zhang H, Zhang J, Junger W, et al. Hyperthermia and associated changes in membrane fluidity potentiate P2X7 activation to promote tumor cell death. Oncotarget. 2017;8:67254-68.

33. Sottile ML, Losinno AD, Fanelli MA, Cuello-Carrión FD, MonttGuevara MM, Vargas-Roig LM, et al. Hyperthermia effects on Hsp27 and Hsp72 associations with mismatch repair (MMR) proteins and cisplatin toxicity in MMR-deficient/proficient colon cancer cell lines. Int J Hyperthermia. 2015;31:464-75.

34. Bhagwandin S, Naffouje S, Salti G. Utility of chemoresponse assay in patients undergoing cytoreductive surgery plus hyperthermic intraperitoneal chemotherapy. Ann Surg Oncol. 2015;22:2573-7.

35. Makrin V, Lev-Chelouche D, Even Sapir E, Paran H, Rabau M, Gutman M. Intraperitoneal heated chemotherapy affects healing of experimental colonic anastomosis: an animal study. J Surg Oncol. 2005;89:18-22.

36. Aghayeva A, Benlice C, Bilgin IA, Atukeren P, Dogusoy G, Demir $F$, et al. The effects of hyperthermic intraperitoneal chemoperfusion on colonic anastomosis: an experimental study in a rat model. Tumori. 2017;103:307-13.

37. Bevanda M, Orsolic N, Basic I, Vukojevic K, Benkovic V, Horvat Knezevic A, et al. Prevention of peritoneal carcinomatosis in mice with combination hyperthermal intraperitoneal chemotherapy and IL-2. Int J Hyperthermia. 2009;25:132-40.

38. Yun Q, Wang SS, Xu S, Yang JP, Fan J, Yang LL, et al. Use of 5 -fluorouracil loaded micelles and cisplatin in thermosensitive chitosan hydrogel as an efficient therapy against colorectal peritoneal carcinomatosis. Macromol Biosci. 2017;17.
39. Cavaliere F, Di Filippo F, Botti C, Cosimelli M, Giannarelli D, Aloe $\mathrm{L}$, et al. Peritonectomy and hyperthermic antiblastic perfusion in the treatment of peritoneal carcinomatosis. Eur J Surg Oncol. 2000;26:486-91.

40. Cavaliere F, Perri P, Di Filippo F, Giannarelli D, Botti C, Cosimelli $M$, et al. Treatment of peritoneal carcinomatosis with intent to cure. J Surg Oncol. 2000;74:41-4.

41. Cavaliere F, De Simone M, Virzì S, Deraco M, Rossi CR, Garofalo A, et al. Prognostic factors and oncologic outcome in 146 patients with colorectal peritoneal carcinomatosis treated with cytoreductive surgery combined with hyperthermic intraperitoneal chemotherapy: italian multicenter study S.I.T.I.L.O. Eur J Surg Oncol. 2011;37:148-54.

42. Pilati P, Mocellin S, Rossi CR, Foletto M, Campana L, Nitti D, et al. Cytoreductive surgery combined with hyperthermic intraperitoneal intraoperative chemotherapy for peritoneal carcinomatosis arising from colon adenocarcinoma. Ann Surg Oncol. 2003;10:508-13.

43. Yonemura Y, Canbay E, Ishibashi H. Prognostic factors of peritoneal metastases from colorectal cancer following cytoreductive surgery and perioperative chemotherapy. Sci World J. 2013;2013:978394.

44. Vaira M, Cioppa T, D’Amico S, de Marco G, D’Alessandro M, Fiorentini $G$, et al. Treatment of peritoneal carcinomatosis from colonic cancer by cytoreduction, peritonectomy and hyperthermic intraperitoneal chemotherapy (HIPEC). Experience of ten years. In Vivo. 2010;24:79-84.

45. Chalret du Rieu Q, White-Koning M, Picaud L, Lochon I, Marsili S, Gladieff L, et al. Population pharmacokinetics of peritoneal, plasma ultrafiltrated and protein-bound oxaliplatin concentrations in patients with disseminated peritoneal cancer after intraperitoneal hyperthermic chemoperfusion of oxaliplatin following cytoreductive surgery: correlation between oxaliplatin exposure and thrombocytopenia. Cancer Chemother Pharmacol. 2014;74:571-82.

46. Virzì S, lusco D, Baratti D, Bonomi S, Grassi A, Kusamura S, et al. Pilot study of adjuvant hyperthermic intraperitoneal chemotherapy in patients with colorectal cancer at high risk for the development of peritoneal metastases. Tumori. 2013;99:589-95.

47. Vaira M, Robella M, Mellano A, Sottile A, De Simone M. Iterative procedures combining cytoreductive surgery and hyperthermic intraperitoneal chemotherapy for isolated peritoneal recurrence. Int J Hyperthermia. 2014;30:565-9.

48. Königsrainer A, Rau B. Cytoreductive surgery (CRS) and hyperthermic intraperitoneal chemotherapy (HIPEC): don't throw the baby out with the bathwater. Pleura Peritoneum. 2018;3:20180131.

49. De Jong LA, Elekonawo FM, de Reuver PR, Bremers AJ, de Wilt JH, Jansman FG, et al. Hyperthermic intraperitoneal chemotherapy with oxaliplatin for peritoneal carcinomatosis: a clinical pharmacological perspective on a surgical procedure. Br J Clin Pharmacol. 2019;85:47-58.

50. Leung V, Huo YR, Liauw W, Morris DL. Oxaliplatin versus Mitomycin $\subseteq$ for HIPEC in colorectal cancer peritoneal carcinomatosis. Eur J Surg Oncol. 2017;43:144-9.

51. Pinto A, Pocard M. Photodynamic therapy and photothermal therapy for the treatment of peritoneal metastasis: a systematic review. Pleura Peritoneum. 2018;3:20180124. 